\title{
Wpływ skazania pracownika na umowny stosunek pracy a ochrona jego danych osobowych
} Impact of employee's conviction on contractual employment
relationship and protection of their personal data

dr hab. Elżbieta Hryniewicz-Lach

Uniwersytet im. Adama Mickiewicza w Poznaniu, Wydział Prawa i Administracji, Katedra Prawa Karnego hryniew@amu.edu.pl ORCID: 0000-0001-6098-7087

Streszczenie Autorka analizuje zakres uprawnień pracodawcy do przetwarzania danych osobowych dotyczących karalności pracownika i osoby ubiegającej się o zatrudnienie, dla potrzeb nawiązania, kontynuacji i rozwiązania umownego stosunku pracy.

Słowa kluczowe: ochrona danych osobowych, karalność, umowny stosunek pracy.

Summary The subject of the study is the scope of employer's rights to process personal data concerning criminal records of an employee and a person applying for employment, for the purposes of establishing, continuing and terminating a contractual employment relationship.

Keywords: protection of personal data, criminal record, employment.

JEL: K31

Str. 33-39

\section{Bibliografia}

Baran, k. w. (2018). Komentarz do art. 55. W: K. W. Baran (red.), Kodeks pracy. Komentarz (teza 6.2). Warszawa.

Florek, L. (2017). Kodeks pracy. Komentarz (art. 221, teza 5). Warszawa.

Gensikowski, P. (2018). Komentarz do art. 180 k.k.w. W: J. Lachowski (red.), Kodeks karny wykonawczy. Komentarz (teza 2). Warszawa.

Grzybowski, S. (1974). O rzekomej konwalidacji nieważnej czynności prawnej. Ruch Prawniczy, Ekonomiczny i Socjologiczny, (3), 37-48.

Jaśkowski, K. (2018). Komentarz do art. 221 k.p. W: K. Jaśkowski, E. Maniewska, Kodeks pracy. Komentarz (teza 2.2). Warszawa. Jaśkowski, K. (2018a). Komentarz do art. 52 k.p. W: K. Jaśkowski, E. Maniewska, Kodeks pracy. Komentarz (tezy 5.1-5.4). Stefańska, B. J. (2008). Prawne i społeczne skutki skazania. Wojskowy Przeglad Prawniczy, (1), 86-100 i (2), 58-72. Waszczyński, J. (1968). Prawne skutki skazania, Państwo i Prawo, (11), 807-818.

Wróbel, W. (2016). Komentarz do art. 41 k.k. W: W. Wróbel, A. Zoll (red.), Kodeks karny. Komentarz (teza 6). Warszawa.

Zalewski, W. (2017). Komentarz do art. 244 k.p. W: M. Królikowski, R. Zawłocki (red.), Kodeks karny. Komentarz (teza 18). Warszawa.

Ziółkowska, K. (2014). Godne zachowanie się pracownika w kontekście wypełniania pracowniczego obowiązku dbałości o dobro zakładu pracy, Studia Etckie, (4), 483-494. 